JPDN ISSN 2579-6461 (Online) ISSN 2460-6324 (Print)

Jurnal Pendidikan Dasar Nusantara

Volume 6| Nomor 1 | Juli 2020|

DOI: https://doi.org/10.29407/jpdn.v6i1.14674

\title{
EFEKTIFITAS BION (BINTANG ONLINE) DALAM MENINGATKAN MOTIVASI BELAJAR SISWA PADA MASA PANDEMI COVID 19 DI KELAS V SDN 1 NGEMBEL
}

\author{
Rendra Handy Abdillah, S.Pd \\ Rendrahandy2@gmail.com \\ SDN 1 Ngembel, Kecamatan Watulimo, Kabupaten Trenggalek
}

\begin{abstract}
Abstrak: Motivasi belajar memiliki hubungan yang sangat erat dengan prestasi siswa, jika hal tersebut tidak bisa di tingkatkan, maka hasil belajar juga tidak dapat optimal. Terlebih pada masa pandemi yang membuat motivasi sebagian siswa menurun. Penggunaan metode reward dan punishmen menjadi sebuah alternatif membuka pintu semangat siswa dalam belajar. Tujuan penelitian ini adalah mengamati penggunaan BION (Bintang Online) dalam meningkatkan motivasi siswa kelas V SDN 1 Ngembel di tengah pandemi dimana physical distancing menjadi konsekuensi logis. Beberapa instrumen pendukungnya yaitu (1) lembar observasi, (2) lembar angket, (3) foto dokumentasi, dan (4) lembar wawancara. Teknik pengumpulan data menggunakan 4 cara yaitu (1) observasi, (2) angket, (3) dokumentasi, dan (4) wawancara. Pengaruh media BION cukup positif dengan di dapatkan data sebagai berikut. Hasil observasi pada akhir siklus dibanding pra siklus dalam pengerjaan tugas naik $22 \%$, prosentase ketepatan waktu naik 27\%, dan pemenuhan KKM naik 22\%. Acuan lain dari angket penelitian, terutama poin ke 3 dimana 100\% anak merasa bahwa BION dapat meningkatkan motivasi Wawancara dengan orang tua juga hampir sama tentang pengaruh BION, dalam memberikan motivasi instrinsik bagi siswa untuk bisa belajar secara mandiri. Berdasarkan data inilah dapat ditarik kesimpulan bahwa penggunaan BION efektif meningkatkan motivasi belajar siswa pada masa pandemi.
\end{abstract}

Kata Kunci: (BION) Bintang Online, Motivasi Belajar, Reward dan Punishmen

\section{THE EFFECTIVENESS OF BION (BINTANG ONLINE) IN IMPROVING THE LEARNING MOTIVATION OF $5^{\text {TH }}$ GRADE STUDENTS IN STATE ELEMENTARY SCHOOL 1 OF NGEMBEL DURING COVID-19 PANDEMIC}

\begin{abstract}
Learning motivation has very strong correlation with student achievement. If the learning motivation cannot be improved, then the achievement will not be optimal as well. Moreover, the current pandemic time decreases students' motivation. The use of reward and punishment method is an alternative to raise students' learning motivation. The purpose of
\end{abstract}


this research was to observe the use of BION (Bintang Online) in improving the learning motivation of $5^{\text {th }}$ grade students in State Elementary School 1 of Ngembel amidst the pandemic where physical distancing is simply a logical consequence. The supporting instruments were (1) observation sheet, (2) questionnaire sheet, (3) documentation photo, and (4) interview sheet. The data were collected using 4 methods: (1) observation, (2) questionnaire, (3) documentation, and (4) interview. The effect of BION medium was fairly positive based on the obtained result. Based on the observation result, the post-cycle, compared to the pre-cycle, had $22 \%$ improvements in assignment completion, $27 \%$ improvement in punctuality, and $22 \%$ improvement in criteria mastery. Another reference came from the questionnaire; in the $3^{\text {rd }}$ point, $100 \%$ of the students felt that BION was able to raise their motivation. The interview with the parents, regarding the effect of BION on the students' intrinsic motivation to learn independently, also showed similar result. Based on these data, it is concluded that BION is effective in improving the students' learning motivation during the pandemic.

Keywords: (BION) Bintang Online, Learning motivation, Reward and Punishmen

\section{PENDAHULUAN}

COVID 19 begitu cepat merebak di sebagian besar belahan bumi, memberikan imbas yang luar biasa terhadap pola kehidupan manusia, tidak terkecuali tentang dunia pendidikan. Salah satu pioner penting pembangun masa depan bangsa itu, terasa di kebiri atas segala batasan yang ada. Saat artikel ini mulai disusun menjadi sebuah best practice utuh pada tanggal 2 Juni 2020, terdapat sekitar 146 negara yang terkena efek pandemi dan diantaranya sudah melakukan penutupan sekolah, dengan total pelajar terdampak sejumlah 1.186.161.728 jiwa (UNESCO, 2020). Perubahan kebijakan ini tentunya melahirkan sistem baru terhadap proses mendidik agar tetap berjalan. Salah satu sistem yang telah banyak diterapkan di berbagai negara adalah pembelajaran secara online atau biasa disebut daring.

Pembelajaran Daring merupakan program penyelenggaraan kelas untuk menjangkau kelompok target yang masif dan luas menggunakan jejaring web (Bilfaqih \& Qomarudin, 2015). Pola ini memungkinkan kita untuk dapat berkomunikasi jarak jauh, tanpa harus bertemu langsung dengan lawan bicara. Fungsi tersebut tentunya akan memudahkan kita pada saat pandemi, dimana akses physical distancing menjadi sebuah konsekuensi logis. Aplikasi yang banyak membantu penulis dalam melaksanakan kegiatan secara online yaitu 
Google formulir, YouTube, Whatshap serta Childreward, dimana antara satu dengan lainnya memiliki fungsi berbeda dalam proses transfer ilmu.

Beberapa minggu pertama dampak dibelakukannya BDR (Belajar di Rumah) cukup memerlukan adaptasi bagi guru, siswa maupun orang tua. Banyak dari keluarga siswa yang hanya memilki Android tidak lebih dari satu buah, bahkan beberapa keluarga belum memiliki gawai sejenis ini dan cukup merepotkan jika harus di timpakan terhadap sarana daring itu sendiri. Kesulitan orang tua pada saat membimbing anak belajar dirumah menjadi sebuah resiko mengingat mendadaknya kegiatan BDR, dampaknya hasil kerja anak menjadi beragam dan tidak sesuai dengan kemampuan di sekolah. Hal lain yang penulis rasakan adalah kurangnya kedisiplinan siswa dalam mengumpulkan hasil kerja, sedikit di antara mereka bahkan ada yang sesekali tidak mengirimkan tugas harian, serta jeda waktu dalam mengumpulkannya tidak teratur meskipun sudah ditegur dan disemangati oleh guru. Kendala tersebut melatar belakangi penulis melakukan kunjungan ke rumah siswa bergilir

Hasil wawancara terhadap orang tua dan siswa dari kunjungan rumah tersebut cukup mengejutkan. Sebagian besar anak sebenarnya sudah di dorong oleh orang tua untuk belajar, tetapi anak sendiri terkadang kurang mengindahkan karena kondisi tidak sama seperti di sekolah. Di rumah anak cenderung merasa bebas, kurangnya target dalam menyelesaikan sesuatu, tidak adanya kompetisi dengan siswa lain untuk mencapai nilai tertinggi, kesibukan kerja orang tua, lingkungan menjenuhkan karena fase social distancing dan lain sebagainya. Hal itu cukup wajar karena memang ada peralihan terhadap proses pendidikan akibat COVID 19. Kumpulan data ini merujuk kepada salah satu hambatan penting yang di alami oleh siswa kelas V SDN 1 Ngembel, yaitu terkait motivasi belajar, yang apabila tetap dibiarkan tentu akan mengarah kepada prestasi belajar siswa yang tidak optimal di masa pendemi ini. Daryanto (dalam Lestari FN, dkk, 2020) bahwa terdapat hal yang mempengaruhi pola kegiatan belajar siswa yaitu faktor psikologis, antara lain minat, bakat, motivasi, kematangan serta kesiapan

Motivasi dan prestasi belajar merupakan dua aspek yang saling mempengaruhi. Prestasi belajar akan menjadi lebih optimal jika di dalamnya terkandung nilai motivasi yang tinggi, itulah kenapa jika seorang siswa berkurang motivasinya, maka prestasi belajarnya pun juga ikut terdampak. Sardiman (dalam Ifni Oktiani, 2017: 224-225) motivasi dapat dikatakan 
sebagai keseluruhan daya penggerak di dalam diri siswa yang menimbulkan, menjamin kelangsungan dan memberikan arah kegiatan belajar, sehingga diharapkan tujuan dapat tercapai. Demi menumbuhkan tingkat motivasi belajar yang lebih baik, maka diperlukan suatu kiat khusus untuk mengubah perilaku siswa, untuk itu salah satu cara yang di ambil oleh penulis adalah dengan menggunakan metode belajar reward dan punishment.

Reward dan punishment adalah sebuah metode belajar yang lazim digunakan oleh pendidik dalam rangka meningkatkan motivasi belajar siswa, karena apapun yang siswa kerjakan akan mendapatkan ganjaran baik itu hadiah ataupun hukuman. Pada dasarnya metode reward dan punishment memiliki tujuan yang sama, yaitu sebagai reinforcement (penguatan) demi tercapainya kemandirian belajar siswa (Putra R.P, dkk. 2018). Berdasarkan kondisi physical distancing yang masih di terapkan, tentu pemberian bentuk metode belajar reward dan punishment, tidak bisa dilakukan secara lansung dan memerlukan sebuah aplikasi online khusus. Oleh karena itu, penulis menggunakan aplikasi mobile yang menarik dan mudah digunakan siswa, dengan media Bintang Prestasi yang dimodifikasi menjadi (BION) Bintang Online, dalam meningkatkan motivasi belajar siswa kelas V SDN 1 Ngembel pada saat pandemi Covid 19.

\section{METODE}

Jenis Penelitian yang digunakan dalam penulisan best practice ini adalah kuantitatif dengan pendekatan deskriptif. Metode Kuantitatif dipilih karena pengalaman dapat terukur secara objektif dan hanya memiliki satu realitas. (Sugiyono:2013) Penelitian kuantitatif menganut filsafat positivisme, fungsi tersebut digunakan untuk meneliti pada jumlah populasi tertentu, analisis data serta bersifat statistik untuk menguji hipotesis yang yang telah di buat. Penelitian tersebut banyak mengacu terhadap penggunaan numerik, mulai dari pengumpulan, penafsiran, serta pemaparan data dari suatu hasil penelitian. Adapun pendekatan yang digunakan adalah deskriptif dengan tujuan untuk menjelaskan hasil ataupun obejek penelitian secara lebih luas. Pengertian deskriptif menurut (Sugiyono:2013) adalah pendekatan yang digunakan untuk memberikan penjelasan atau gambaran merujuk pada data yang telah terkumpul tanpa membuat kesimpulan yang berlaku untuk umum. 
Subjek penelitian ini merupakan siswa kelas V SDN 1 Ngembel, Kecamatan Watulimo, Kabupaten Trenggalek dengan jumlah 22 siswa, terdiri dari 15 laki laki dan 7 perempuan. Waktu pelaksanaan penelitian di ambil ketika kegiatan BDR dilaksanakan selama masa pandemi. Pengambilan data observasi selama 1 minggu, 6(enam) hari aktif mulai hari senin sampai sabtu pada awal pelaksanaan metode. Data terkumpul kemudian di analisis untuk membuktikan hipotesis yang telah di buat oleh penulis terkait peningkatan motivasi siswa menggunakan media BION (Bintang Online). BION merupakan system reward berupa pemberian icon bintang secara online untuk siswa yang telah selesai dalam melaksanakan tugasnya. Jika siswa tidak mengerjakan tugas, maka tidak akan mendapatkan bintang. Punishment diberikan ketika 3 (tiga) hari secara berturut turut tidak mengerjakan tugas, maka jumlah bintangnya akan dikurangi.

Instrumen merupakan alat yang digunakan oleh peneliti untuk mengumpulkan data (Sugiyono: 2013). Beberapa instrumen pendukungnya yaitu (1) Lembar observasi, (2) lembar angket, (3) Foto dokumentasi, dan (4) lembar wawancara. Teknik pengumpulan data menggunakan 4 cara yaitu (1) Observasi, (2) Angket, (3) Dokumentasi, dan (4) Wawancara. Observasi merujuk terhadap perolehan bintang yang telah siswa kumpulkan dengan aplikasi mobile bernama childreward, meskipun beberapa siswa tetap menggunakan whatshap, karena ada beberapa smartphone yang tidak support untuk aplikasi ini. Cara penggunaan aplikasi sudah penulis upload pada akun youtube Ruang Siswa dengan judul "penggunaan childreward untuk meningkatkan motivasi siswa”. Angket yang digunakan dalam pengumpulan data berisi tentang hambatan yang siswa pada masa BDR serta terkait pemanfaatan media BION dengan 3 (tiga) option jawaban Y(ya), T (Tidak) dan TT (Tidak Tahu). Dokumentasi berisi hasil kerja berupa foto dan video, baik itu karya, portofolio ataupun hasil kerja lain yang dikirimkan oleh siswa. Wawancara dilakukan pada awal kegiatan BDR serta pada akhir pembelajaran semester 2 tahun ajaran 2019/2020 sebelum liburan kenaikan kelas dilaksanakan baik kepada orang tua dan siswa.

Tabel 1. Instrumen Angket Penelitian 


\begin{tabular}{|c|c|c|}
\hline 1 & $\begin{array}{l}\text { Apakah selama masa BDR (Belajar di Rumah) kalian sering melakukan } \\
\text { kegiatan belajar? }\end{array}$ & $\begin{array}{c}\text { YA Untuk Sering } \\
\text { TIDAK Untuk Jarang } \\
\text { TIDAK TAHU }\end{array}$ \\
\hline 2 & Apakah pengerjaan tugas sering di bantu oleh orang tua ? & $\begin{array}{c}\text { YA Untuk Sering } \\
\text { TIDAK Untuk Jarang } \\
\text { TIDAK TAHU }\end{array}$ \\
\hline 3 & $\begin{array}{l}\text { Apakah BION dapat meningkatkan motivasi kalian dalam mengerjakan } \\
\text { tugas? }\end{array}$ & $\begin{array}{l}\text { YA / TIDAK / } \\
\text { TIDAK TAHU }\end{array}$ \\
\hline 4 & $\begin{array}{l}\text { Apakah jika tidak ada reward dalam BION, kalian masih rajin dalam } \\
\text { mengerjakan tugas? }\end{array}$ & $\begin{array}{l}\text { YA / TIDAK / } \\
\text { TIDAK TAHU }\end{array}$ \\
\hline 5 & $\begin{array}{l}\text { Lebih mudah menerima pembelajaran, di rumah atau di sekolah menurut } \\
\text { kalian? }\end{array}$ & $\begin{array}{c}\text { YA Untuk Sekolah } \\
\text { TIDAK Untuk Rumah } \\
\text { TIDAK TAHU }\end{array}$ \\
\hline 6 & $\begin{array}{l}\text { Jika bisa memilih, kalian memilih belajar di rumah atau di sekolah untuk } \\
\text { seterusnya? }\end{array}$ & $\begin{array}{c}\text { YA Untuk Sekolah } \\
\text { TIDAK Untuk Rumah } \\
\text { TIDAK TAHU }\end{array}$ \\
\hline
\end{tabular}

\section{Tabel 2. Instrumen Pertanyaan Wawancara}

\begin{tabular}{ll}
\hline No & Pertanyaan \\
\hline $\mathbf{1}$ & Bagaimana perbedaan proses belajar siswa di rumah dan di sekolah? \\
$\mathbf{2}$ & Apakah terjadi peningkatan atau justru penurunan, contohnya seperti apa? \\
$\mathbf{3}$ & Hal apa saja yang melatar belakangi peningatan atau penurunan kualitas belajar tersebut? \\
$\mathbf{4}$ & Apakah anak sering meminta bantuan terhadap orang tua ? \\
$\mathbf{5}$ & Apakah BION berpengaruh terhadap proses belajar, bentuknya pengaruhnya seperti apa? \\
$\mathbf{6}$ & Setujukah jika kegiatan pembelajaran di rumah dijadikan pembelajaran permanen, sebutkan alasan? \\
\hline
\end{tabular}

\section{HASIL}

Tabel 3. Data Hasil Observasi Siswa dalam Mengerjakan Tugas

\begin{tabular}{|c|c|c|c|c|c|c|c|c|c|c|c|c|c|c|c|c|c|c|c|c|c|c|}
\hline \multirow[t]{2}{*}{ No } & \multirow[t]{2}{*}{ Nama } & \multicolumn{3}{|c|}{ Pra Siklus } & \multicolumn{6}{|c|}{$\begin{array}{l}\text { Pengumpulan } \\
\text { Tugas/Hari }\end{array}$} & \multicolumn{6}{|c|}{$\begin{array}{c}\text { Ketepatan } \\
\text { Waktu/Hari }\end{array}$} & \multicolumn{6}{|c|}{$\begin{array}{l}\text { Nilai di Atas } \\
\text { KKM/Hari }\end{array}$} \\
\hline & & PT & KW & KKM & 1 & 2 & 3 & 4 & 5 & 6 & 1 & 2 & 3 & 4 & 5 & 6 & 1 & 2 & 3 & 4 & 5 & 6 \\
\hline 1 & IQBAL ANDIKA K & & & & $\checkmark$ & & $\checkmark$ & $\checkmark$ & $\checkmark$ & $\checkmark$ & $\checkmark$ & & $\checkmark$ & $\checkmark$ & $\checkmark$ & $\checkmark$ & $\checkmark$ & & & $\checkmark$ & $\checkmark$ & $\checkmark$ \\
\hline 2 & ADIN ANANDA P & $\checkmark$ & $\checkmark$ & $\checkmark$ & $\checkmark$ & $\checkmark$ & $\checkmark$ & $\checkmark$ & $\checkmark$ & $\checkmark$ & $\checkmark$ & $\checkmark$ & $\checkmark$ & $\checkmark$ & $\checkmark$ & $\checkmark$ & $\checkmark$ & $\checkmark$ & $\checkmark$ & $\checkmark$ & $\checkmark$ & $\checkmark$ \\
\hline 3 & ALFINDRA FAJAR Y & $\checkmark$ & & $\checkmark$ & $\checkmark$ & $\checkmark$ & $\checkmark$ & $\checkmark$ & $\checkmark$ & $\checkmark$ & $\checkmark$ & $\checkmark$ & $\checkmark$ & $\checkmark$ & $\checkmark$ & $\checkmark$ & $\checkmark$ & $\checkmark$ & $\checkmark$ & $\checkmark$ & $\checkmark$ & $\checkmark$ \\
\hline 4 & CEVINA RINTA Y & $\checkmark$ & $\checkmark$ & $\checkmark$ & $\checkmark$ & $\checkmark$ & $\checkmark$ & $\checkmark$ & $\checkmark$ & $\checkmark$ & $\checkmark$ & $\checkmark$ & $\checkmark$ & $\checkmark$ & $\checkmark$ & $\checkmark$ & $\checkmark$ & $\checkmark$ & $\checkmark$ & $\checkmark$ & $\checkmark$ & $\checkmark$ \\
\hline
\end{tabular}




\begin{tabular}{|l|l|c|c|c|c|c|c|c|c|c|c|c|c|c|c|c|c|c|c|c|c|c|}
\hline 5 & DENY NURWANTO & $\checkmark$ & $\checkmark$ & $\checkmark$ & $\checkmark$ & $\checkmark$ & & $\checkmark$ & $\checkmark$ & $\checkmark$ & $\checkmark$ & $\checkmark$ & & $\checkmark$ & $\checkmark$ & $\checkmark$ & $\checkmark$ & $\checkmark$ & & $\checkmark$ & $\checkmark$ & $\checkmark$ \\
\hline 6 & DIELEN RAKA S & $\checkmark$ & $\checkmark$ & $\checkmark$ & $\checkmark$ & $\checkmark$ & $\checkmark$ & $\checkmark$ & $\checkmark$ & $\checkmark$ & $\checkmark$ & $\checkmark$ & $\checkmark$ & $\checkmark$ & $\checkmark$ & $\checkmark$ & $\checkmark$ & $\checkmark$ & $\checkmark$ & $\checkmark$ & $\checkmark$ & $\checkmark$ \\
\hline 7 & ELLY REVIANA F & $\checkmark$ & $\checkmark$ & $\checkmark$ & $\checkmark$ & $\checkmark$ & $\checkmark$ & $\checkmark$ & $\checkmark$ & $\checkmark$ & $\checkmark$ & $\checkmark$ & $\checkmark$ & $\checkmark$ & $\checkmark$ & $\checkmark$ & $\checkmark$ & $\checkmark$ & $\checkmark$ & $\checkmark$ & $\checkmark$ & $\checkmark$ \\
\hline 8 & GARLIN AULIA I & $\checkmark$ & $\checkmark$ & $\checkmark$ & $\checkmark$ & $\checkmark$ & $\checkmark$ & $\checkmark$ & $\checkmark$ & $\checkmark$ & $\checkmark$ & $\checkmark$ & $\checkmark$ & $\checkmark$ & $\checkmark$ & $\checkmark$ & $\checkmark$ & $\checkmark$ & $\checkmark$ & $\checkmark$ & $\checkmark$ & $\checkmark$ \\
\hline 9 & JOHANES NANDRA S & & & & $\checkmark$ & $\checkmark$ & $\checkmark$ & $\checkmark$ & $\checkmark$ & $\checkmark$ & $\checkmark$ & $\checkmark$ & $\checkmark$ & $\checkmark$ & $\checkmark$ & $\checkmark$ & $\checkmark$ & $\checkmark$ & $\checkmark$ & $\checkmark$ & $\checkmark$ & $\checkmark$ \\
\hline 10 & KHOLILURROHMAN & $\checkmark$ & $\checkmark$ & $\checkmark$ & $\checkmark$ & $\checkmark$ & $\checkmark$ & $\checkmark$ & $\checkmark$ & $\checkmark$ & $\checkmark$ & $\checkmark$ & $\checkmark$ & $\checkmark$ & $\checkmark$ & $\checkmark$ & $\checkmark$ & $\checkmark$ & $\checkmark$ & $\checkmark$ & $\checkmark$ & $\checkmark$ \\
\hline 11 & MARIO CAHYO S & & & & & $\checkmark$ & $\checkmark$ & $\checkmark$ & $\checkmark$ & $\checkmark$ & & $\checkmark$ & $\checkmark$ & $\checkmark$ & $\checkmark$ & $\checkmark$ & & $\checkmark$ & $\checkmark$ & $\checkmark$ & $\checkmark$ & $\checkmark$ \\
\hline 12 & MARVIN RICKI A P & $\checkmark$ & $\checkmark$ & $\checkmark$ & $\checkmark$ & $\checkmark$ & $\checkmark$ & $\checkmark$ & $\checkmark$ & $\checkmark$ & $\checkmark$ & $\checkmark$ & $\checkmark$ & $\checkmark$ & $\checkmark$ & $\checkmark$ & $\checkmark$ & $\checkmark$ & $\checkmark$ & $\checkmark$ & $\checkmark$ & $\checkmark$ \\
\hline 13 & MOHAMAD ALFIN N & $\checkmark$ & $\checkmark$ & $\checkmark$ & $\checkmark$ & $\checkmark$ & $\checkmark$ & $\checkmark$ & $\checkmark$ & $\checkmark$ & $\checkmark$ & $\checkmark$ & $\checkmark$ & $\checkmark$ & $\checkmark$ & $\checkmark$ & $\checkmark$ & $\checkmark$ & $\checkmark$ & $\checkmark$ & $\checkmark$ & $\checkmark$ \\
\hline 14 & MUKTI ANGGARA P & $\checkmark$ & $\checkmark$ & $\checkmark$ & $\checkmark$ & $\checkmark$ & $\checkmark$ & $\checkmark$ & $\checkmark$ & $\checkmark$ & $\checkmark$ & $\checkmark$ & $\checkmark$ & $\checkmark$ & $\checkmark$ & $\checkmark$ & $\checkmark$ & $\checkmark$ & $\checkmark$ & $\checkmark$ & $\checkmark$ & $\checkmark$ \\
\hline 15 & NUR ROMAN DWI C & & & & & & $\checkmark$ & & $\checkmark$ & & & & & & $\checkmark$ & & & & $\checkmark$ & $\checkmark$ & \\
\hline 16 & QNESTIN SEPTIA N & $\checkmark$ & $\checkmark$ & $\checkmark$ & $\checkmark$ & $\checkmark$ & $\checkmark$ & $\checkmark$ & $\checkmark$ & $\checkmark$ & $\checkmark$ & $\checkmark$ & $\checkmark$ & $\checkmark$ & $\checkmark$ & $\checkmark$ & $\checkmark$ & $\checkmark$ & $\checkmark$ & $\checkmark$ & $\checkmark$ & $\checkmark$ \\
\hline 17 & RIANI DWI N & $\checkmark$ & $\checkmark$ & $\checkmark$ & $\checkmark$ & $\checkmark$ & $\checkmark$ & $\checkmark$ & $\checkmark$ & $\checkmark$ & $\checkmark$ & $\checkmark$ & $\checkmark$ & $\checkmark$ & $\checkmark$ & $\checkmark$ & $\checkmark$ & $\checkmark$ & $\checkmark$ & $\checkmark$ & $\checkmark$ & $\checkmark$ \\
\hline 18 & RIFKI AHMAD AFIF & $\checkmark$ & $\checkmark$ & $\checkmark$ & $\checkmark$ & $\checkmark$ & $\checkmark$ & $\checkmark$ & $\checkmark$ & $\checkmark$ & $\checkmark$ & $\checkmark$ & $\checkmark$ & $\checkmark$ & $\checkmark$ & $\checkmark$ & $\checkmark$ & $\checkmark$ & $\checkmark$ & $\checkmark$ & $\checkmark$ & $\checkmark$ \\
\hline 19 & SELY AMEYLYA P & $\checkmark$ & $\checkmark$ & $\checkmark$ & $\checkmark$ & $\checkmark$ & $\checkmark$ & $\checkmark$ & $\checkmark$ & $\checkmark$ & $\checkmark$ & $\checkmark$ & $\checkmark$ & $\checkmark$ & $\checkmark$ & $\checkmark$ & $\checkmark$ & $\checkmark$ & $\checkmark$ & $\checkmark$ & $\checkmark$ & $\checkmark$ \\
\hline 20 & SUNU YANUAR A & $\checkmark$ & $\checkmark$ & $\checkmark$ & $\checkmark$ & $\checkmark$ & $\checkmark$ & $\checkmark$ & $\checkmark$ & $\checkmark$ & $\checkmark$ & $\checkmark$ & $\checkmark$ & $\checkmark$ & $\checkmark$ & $\checkmark$ & $\checkmark$ & $\checkmark$ & $\checkmark$ & $\checkmark$ & $\checkmark$ & $\checkmark$ \\
\hline 21 & WIRI DENIATI & & & & & $\checkmark$ & $\checkmark$ & $\checkmark$ & & $\checkmark$ & & $\checkmark$ & $\checkmark$ & & & $\checkmark$ & & $\checkmark$ & $\checkmark$ & $\checkmark$ & & $\checkmark$ \\
\hline 22 & TRISTAN JULIAN & & & & $\checkmark$ & $\checkmark$ & & $\checkmark$ & $\checkmark$ & $\checkmark$ & $\checkmark$ & & & $\checkmark$ & $\checkmark$ & $\checkmark$ & $\checkmark$ & $\checkmark$ & & $\checkmark$ & $\checkmark$ & $\checkmark$ \\
\hline
\end{tabular}

Keterangan

PT : Pengumpulan Tugas

KW : Ketepatan Waktu (Pengumpulan Tugas mulai $08.00-14.00 \mathrm{WIB}$ )

KKM : Kriteria Ketuntasan Minimal (Pengumpulan Tugas siswa harus baik, nilai di atas KKM)

peningkatan terhadap proses kegiatan anak dalam mengerjakan tugas harian. Prosentase pengumpulan tugas sebelum dilakukan siklus sebesar 73\%, pada akhir penelitian menjadi 95\%. Prosentase ketepatan waktu dalam mengerjakan tugas mulai dengan 68\% menjadi 95\%. Prosentase pemenuhan KKM 73\% meningat sampai 95\% pada akhir penelitian.

Tabel 4. Data Hasil Observasi Angket Penelitian

\begin{tabular}{|c|c|c|c|c|c|c|c|c|c|c|c|c|c|c|c|c|c|c|c|}
\hline \multirow{3}{*}{ No } & \multirow{3}{*}{ Nama } & \multicolumn{18}{|c|}{ Indikator Angket } \\
\hline & & \multicolumn{3}{|c|}{1} & \multicolumn{3}{|c|}{2} & \multicolumn{3}{|c|}{3} & \multicolumn{3}{|c|}{4} & \multicolumn{3}{|c|}{5} & \multicolumn{3}{|c|}{6} \\
\hline & & $\mathrm{Y}$ & $\mathrm{T}$ & $\begin{array}{l}\mathrm{T} \\
\mathrm{T}\end{array}$ & $\mathrm{Y}$ & $\mathrm{T}$ & $\begin{array}{l}\mathrm{T} \\
\mathrm{T}\end{array}$ & $\mathrm{Y}$ & $\mathrm{T}$ & $\begin{array}{l}\mathrm{T} \\
\mathrm{T}\end{array}$ & $\mathrm{Y}$ & $\mathrm{T}$ & $\begin{array}{l}\mathrm{T} \\
\mathrm{T}\end{array}$ & $\mathrm{Y}$ & $\mathrm{T}$ & $\begin{array}{l}\mathrm{T} \\
\mathrm{T}\end{array}$ & $\mathrm{Y}$ & $\mathrm{T}$ & $\begin{array}{l}\mathrm{T} \\
\mathrm{T}\end{array}$ \\
\hline 1 & IQBAL ANDIKA K & $\checkmark$ & & & & $\checkmark$ & & $\checkmark$ & & & $\checkmark$ & & & $\checkmark$ & & & $\checkmark$ & & \\
\hline 2 & ADIN ANANDA PUTRI & $\checkmark$ & & & & $\checkmark$ & & $\checkmark$ & & & $\checkmark$ & & & $\checkmark$ & & & $\checkmark$ & & \\
\hline 3 & ALFINDRA FAJAR YUKI A & $\checkmark$ & & & & $\checkmark$ & & $\checkmark$ & & & $\checkmark$ & & & $\checkmark$ & & & $\checkmark$ & & \\
\hline 4 & CEVINA RINTA YUANA & $\checkmark$ & & & & $\checkmark$ & & $\checkmark$ & & & $\checkmark$ & & & $\checkmark$ & & & $\checkmark$ & & \\
\hline 5 & DENY NURWANTO & $\checkmark$ & & & & $\checkmark$ & & $\checkmark$ & & & $\checkmark$ & & & $\checkmark$ & & & $\checkmark$ & & \\
\hline
\end{tabular}




\begin{tabular}{|l|l|c|c|c|c|c|c|c|c|c|c|c|c|c|c|c|c|c|}
\hline 6 & DIELEN RAKA SANSANA & $\checkmark$ & & $\checkmark$ & & & $\checkmark$ & & & $\checkmark$ & & $\checkmark$ & & $\checkmark$ & & \\
\hline 7 & ELLY REVIANA FIENTRI & $\checkmark$ & & & $\checkmark$ & $\checkmark$ & & $\checkmark$ & & & $\checkmark$ & & $\checkmark$ & & \\
\hline 8 & GARLIN AULIA ISNIASARI & $\checkmark$ & & & $\checkmark$ & $\checkmark$ & & $\checkmark$ & & & $\checkmark$ & & $\checkmark$ & & \\
\hline 9 & JOHANES NANDRA S & $\checkmark$ & & & $\checkmark$ & $\checkmark$ & & $\checkmark$ & & & $\checkmark$ & & $\checkmark$ & & \\
\hline 10 & KHOLILURROHMAN & $\checkmark$ & & & $\checkmark$ & $\checkmark$ & & $\checkmark$ & & & $\checkmark$ & & $\checkmark$ & & \\
\hline 11 & MARIO CAHYO SEPTA ADI & $\checkmark$ & & $\checkmark$ & & & $\checkmark$ & & $\checkmark$ & & & $\checkmark$ & & $\checkmark$ & & \\
\hline 12 & MARVIN RICKI ANDIKA P & $\checkmark$ & & $\checkmark$ & & & $\checkmark$ & & $\checkmark$ & & & $\checkmark$ & & $\checkmark$ & & \\
\hline 13 & MOHAMAD ALFIN NUR R & $\checkmark$ & & $\checkmark$ & & & $\checkmark$ & & $\checkmark$ & & & $\checkmark$ & & $\checkmark$ & & \\
\hline 14 & MUKTI ANGGARA PUTRA & $\checkmark$ & & $\checkmark$ & & & $\checkmark$ & & $\checkmark$ & & & $\checkmark$ & & $\checkmark$ & & \\
\hline 15 & NUR ROMAN DWI C & $\checkmark$ & & & $\checkmark$ & & $\checkmark$ & & $\checkmark$ & & & $\checkmark$ & & $\checkmark$ & & \\
\hline 16 & QNESTIN SEPTIA NUR A & $\checkmark$ & & & $\checkmark$ & & $\checkmark$ & & $\checkmark$ & & & $\checkmark$ & & & $\checkmark$ & & \\
\hline 17 & RIANI DWI NINGTYAS & $\checkmark$ & & & $\checkmark$ & $\checkmark$ & & $\checkmark$ & & $\checkmark$ & & $\checkmark$ & & \\
\hline 18 & RIFKI AHMAD AFIF & $\checkmark$ & & & $\checkmark$ & $\checkmark$ & & $\checkmark$ & & $\checkmark$ & & $\checkmark$ & & \\
\hline 19 & SELY AMEYLYA PUTRI & $\checkmark$ & & & $\checkmark$ & $\checkmark$ & & $\checkmark$ & & & $\checkmark$ & & $\checkmark$ & & \\
\hline 20 & SUNU YANUAR ANANDA & $\checkmark$ & & $\checkmark$ & & & $\checkmark$ & & $\checkmark$ & & $\checkmark$ & & $\checkmark$ & & \\
\hline 21 & WIRI DENIATI & $\checkmark$ & & & $\checkmark$ & & $\checkmark$ & & $\checkmark$ & & & $\checkmark$ & & $\checkmark$ & & \\
\hline 22 & TRISTAN JULIAN & $\checkmark$ & & & $\checkmark$ & $\checkmark$ & & $\checkmark$ & & $\checkmark$ & & $\checkmark$ & & \\
\hline
\end{tabular}

Keterangan
Y : Ya
T : Tidak
TT : Tidak Tahu

Berdasarkan tabel observasi 4 terdapat prosentase kegiatan yang siswa lakukan di rumah. Indikator 1 untuk seringnya belajar dirumah, jawaban "ya" sebesar 100\%. Indikator 2 untuk bantuan kerja dari orang tua, jawaban "ya" sebanyak 27\%, dan "tidak" sebanyak 73\%. Indikator 3 untuk efektifitas BION, responden 100\% menjawab “ya”. Indikator 4 untuk pengaruhnya BION dan Reward, jawaban "ya" sebesar 95\% dan jaawaban "Tidak" sebesar 5\%. Indikator 5 tentang mudahnya menerima pelajaran, jawaban "ya / Di sekolah" sebesar 100\%. Indikator 6 untuk memilih proses belajar, jawaban "ya / Di sekolah" sebesar 100\% 


\section{PEMBAHASAN}

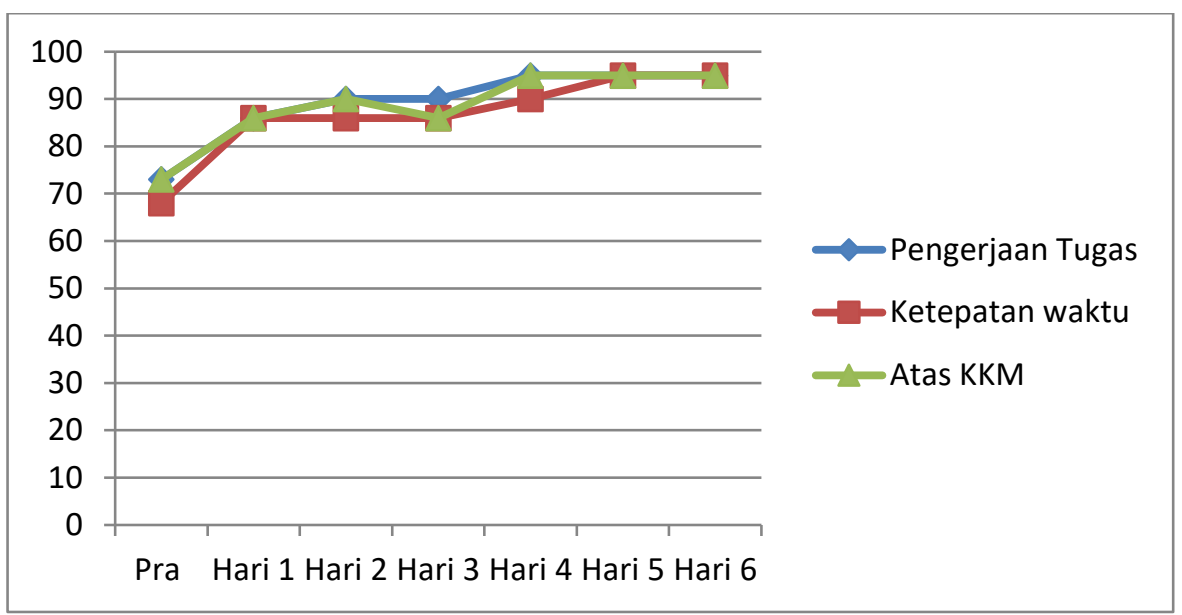

\section{Grafik 1. Deskripsi Hasil Observasi Siswa Mengerjakan Tugas}

Berdasarkan grafik 1 pada hasil obesrvasi siswa dalam mengerjakan tugas terkait pengaruh BION di atas, diperoleh data bahwa terjadi tren kenaikan motivasi belajar siswa sepanjang waktu. Kesimpulan ini merujuk terhadap 3 indikator yang mengalami peningkatan, yaitu pengerjaan tugas, ketepatan waktu serta nilai KKM. Secara umum memang sebelum adanya siklus, sebagian besar anak sudah mengumpulkan tugasnya, tetapi dari waktu ke waktu terjadi penurunan pengumpulan. Hal ini diakibatkan pengaruh BDR yang luar biasa mengubah pola belajar anak, dari yang biasanya secara penuh terkontrol di sekolah, menjadi longgar pada saat di rumah. Berdasarkan masalah tersebut diperlukan metode reward dan punishmen dalam meningkatkan motivasi belajar siswa, seperti yang dilakukan pada semester 1 dengan penggunaan papan bintang manual yang di tempel di tembok kelas V.

Indikator 1 terkait pengerjaan tugas, pada awal siklus yang sebesar $73 \%$ berangsur menjadi 95\% pada akhir siklus. Beberapa anak yang tidak bisa mengumpulkan tugas secara rutin, umumnya karena tidak memiliki hape sendiri, oleh karena itu terkadang informasi penugasan dari guru tidak tersampaikan secara penuh. Lain hal lagi, ada lebih dari satu anak yang harus meminjam handphone tetangga pada saat mengirim ke gurunya. Kondisi daerah pegunungan dengan minimnya sinyal serta ketersediaan handphone menjadi salah satu faktor utama berkurangnya penugasan siswa pada masa BDR. Indikator 1 ini sekaligus mempengaruhi indikator 2 dan 3. Jika indikator 1 tidak dikerjakan, maka indikator 2 dan 3 
secara otomatis juga kosong. Oleh sebab itu, grafik indikator 1 lebih tinggi daripada indikaktor 2 dan 3.

Indikator 2 tentang ketepatan waktu, berangsur meningkat mulai dari $68 \%$ menjadi 95\% pada akhir siklus. Ketepatan waktu ini banyak dipengaruhi oleh ketersediaan hape di rumah. Terkadang anak harus menunggu sampai orang tua pulang sehingga tidak jarang pengumpulan tugas terjadi pada akhir waktu pengumpulan. Ketepatan waktu menjadi salah satu indikator peningkatan motivasi belajar, karena dengan ketepatan waktu tercermin kedisiplinan anak dalam menyelesaikan tugas, bukan hanya dalam bentuk kualitas hasil kerja. Pengumpulan tugas dengan waktu yang sesuai, akan mendidik anak dalam manajemen waktu serta prioritas kerja di rumah tentang apa yang wajib dikerjakan misalnya tugas ataupun yang bisa di tunda misalnya bermain.

Indikator 3 tentang ketuntasan KKM secara umum hampir sejalan dengan indikator 1 terkait pengumpulan tugas, dengan prosentase pra siklus sebesar $73 \%$ menjadi $95 \%$ pada akhir siklus. Ada penurunan nilai memang pada hari ke 3, tapi penulis rasa, penurunan akan hasil kerja siswa adalah hal yang biasa, karena kita tahu sendiri bahwa prosentase pada angket tentang bimbingan dari orang tua cukup sedikit. Sampai pada akhir siklus pola BION, memang belum bisa menemui titik puncak 100\%, karena terdapat salah satu anak yang jarang mengumpulkan tugas. Berdasar alasan sulitnya sinyal dan tidak adanya paket data membuat tugas yang dikumpulkan tidak optimal, meskipun demikian dengan BION anak tersebut sesekali mengumpulkan tugas meskipun tidak rutin. Data yang diperoleh di atas merujuk bahwa metode reward dan punishmen, dalam bentuk online sangat membantu siswa dalam menyelesaikan tanggung jawab kerja pada masa pandemi. Hal tersebut sesuai dengan penryataan (Maulidia, Isna, 2019) bahwa penguatan (reinforcement) berupa reward dan punishment bisa dikatakan berjalan dengan baik, karena meminimalisir perilaku negatif serta meningkatkan semangat belajar siswa, sehingga menjadi sarana dalam meningkatkan motivasi belajar pada siswa serta mengurangi kesalahan yang dilakukan. 


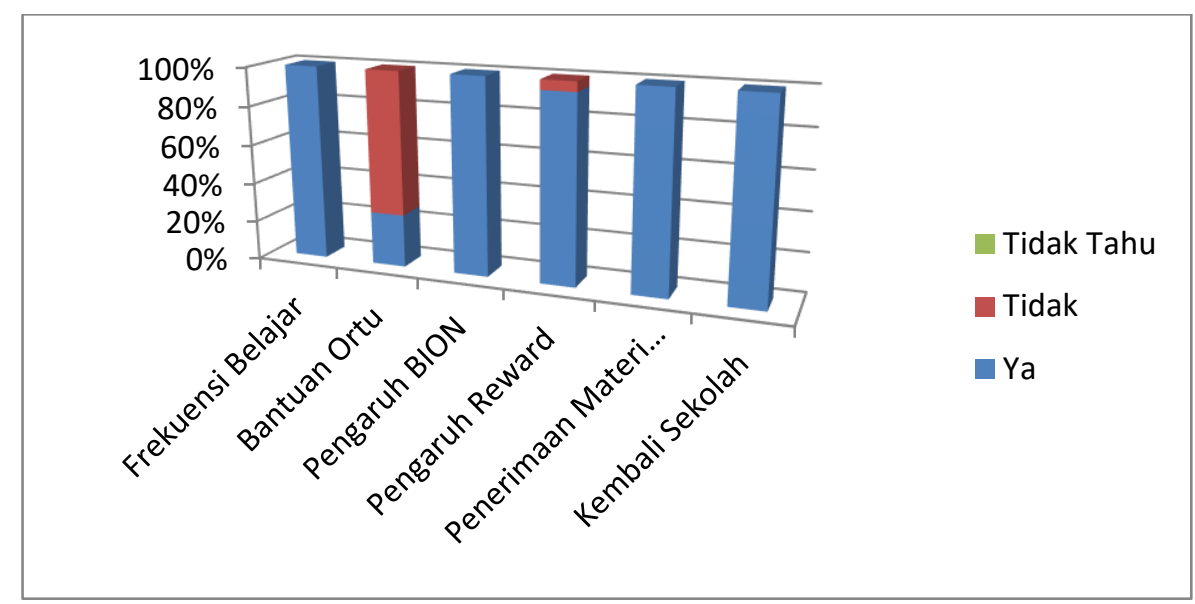

Grafik 2. Deskripsi Hasil Observasi Siswa Mengerjakan Tugas

Berdasarkan grafik 2 di atas, dapat kita jaabarkan sebagai berikut. Indikator 1 tentang frekuensi belajar, 100\% siswa sering melakukan kegiatan belajar dirumah pada masa pandemi. Indikator ini menunjukan bahwa tanpa perintah guru pun mereka masih memiliki semnagat dalam menuntut ilmu. Indikator 2 menunjukan bantuan belajar orang tua yang ternyata cukup rendah, hanya $27 \%$ dari total seluruh siswa atau sebayak 6 siswa saja yang sering mendapatkan bimbingan, sisanya $73 \%$ atau sebanyak 16 siswa mereka sering belajar mandiri. Indikator ini secara tidak langdung menunjukan bagaimana BION mengingkatkan kesadaran siswa meskipun tanpa bantuan orang tua. Pengawasan dan bimbingan yang kurang optimal dari orang tua sebagai faktor ekstrinsik, ditutupi oleh factor instrinsik dari siswa itu sendiri dengan semangat belajar mengumpulkan bintang.

Indikator 3 menunjukan tingkat keberhasilan BION dalam meningkatkan motivasi belajar, sebanyak 100\% atau total seluruh siswa. Indikator ini menjadi bukti konkrit bahwa metode ini cukup berhasil dalam meningkatkan motivasi belajar siswa dirumah, yang notabene pendampigan atau bimbingan orang tua cukup minim seperti yang kita ketahui pada butir ke 2 . Indikator 4 tentang pengaruh reward atau hadiah, hanya 1 siswa saja yang mengaku memiliki pengaruh terahdap BION, atau sekitar 5\%, dan sisanya sebanyak 95\% menjawab tidak. Kecil atau besar pengaruh reward, menurut pandangan penulis sebenarnya tetap ada, dibuktikan pada saat pemberian reward jam tangan pada semester 1 yang dilakukan untuk anak yang bintangnya penuh, pada saat itu pemberian bintang dilakukan di papan bintang yang dipasang di tembok sekolah sebelum masa pandemic dengan total bintang sebanyak 25 buah. Tidak harus mewah dalam menentukan hadiah, bentuk pengahargaan 
yang diterima siswa atas kerja keras, lebih membahagiakan daripada barang mewah yang tanpa disertai usaha.

Indikator 5 tentang kemudahan penerimaan materi, 100\% anak memilih lebih mudah belajar di sekolah daripada di rumah. Butir poin ke 5 ini cukup jelas, karena keterbatasan tatap muka dengan guru menjadikan penerimaan pelajaran siswa di rumah semakin sulit. Indikator 6 tentang keinginan belajar antara di rumah dan disekolah, seluruh anak memilih untuk belajar di sekolah. Pada poin terakhir ini terlihat anak sangat merindukan untuk belajar di sekolah. Proses belajar dan bermain, menjadi salah satu hal yang mereka rindukan pada masa pandemi ini, dimana bukan hanya terkait proses menerima pelajaran di sekolah, tetapi dunia bermain mereka juga ikut terenggut dengan adanya pandemi ini. Disinilah peran BION menjadi sedikit penawar, adanya tantangan dalam meraih bintang menjadikan anak mengenang masa berlomba dalam mencari ilmu dan nilai pada saat di kelas dulu.

Pembahasan selanjutnya mengacu terhadap hasil wawancara antara guru dengan orang tua siswa, hasilnya dijabarkan sebagai berikut. Pada proses pembelajaran antara di sekolah dan di rumah jelas sekali terjadi perbedaan yang mencolok. Proses ini tidak terlepas dari BDR yang dilakukan mendadak, sehingga semua pihak merasa belum siap menerima, terlebih jika orang tua sama-sama bekerja di luar rumah. Intensitas dan kualitas dalam membibing anak akan tidak optimal. Biasanya jika setiap hari orang tua mengantar anak ke sekolah untuk belajar, sekarang mereka yang harus mengajar secara mandiri dirumah disamping tugas yang diberikan guru. Tentu saja hal ini menyebabkan kualitas materi yang diterima menurun selama massa BDR. Banyak hal yang mempengarhi, mulai dari pekerjaan orang tua, cukup sulitnya mengontrol pada beberapa anak untuk tetap di rumah, kurangnya fasilitas belajar misalnya hape atau paket data dan sebagainya.

Sebagian orang tua sebenarnya sudah mengusahakan anaknya agar mau dibimbing, tetapi anak terkadang tidak bersedia karena mungkin ada perbedaan cara mendidik antara guru dan orang tua. Disinilah letak perbedaan, dimana profesi mengajar itu menurut penulis tidak segampang yang terlihat di permukaan. Melihat lewat kacamata positif sebenarnya ada kelebihan ketika orang tua ditimpakan kegiatan BDR. (Puwanto, dkk, 2020) menunjukan bahwa pemanfaatan teknologi untuk orang tua, menjadi semakin meningkat akibat keterpaksaan mengajar anak dirumah pada masa pandemi. Beberapa orang tua ada yang 
memang dari awal mengerti apa itu BION, tetapi sebagian lagi baru mengerti ketika penulis menjelaskan kepadanya tentang kegiatan anak selama masa pandemi yang berhubungan dengan media tersebut.

Secara garis besar mereka sepakat bahwa terjadi perubahan pada anak, karena anak jadi terpacu semangatnya untuk mengumpulkan bintang dan mendapatkan reward. Sedikit tidak sinkron memang terhadap angket yang diberika pada poin ke 4 tentang reward, tetapi memang begitulah adanya menurut pengamatan penulis. Bahwa bentuk reward masih dapat meningkatkan motivasi belajar, meskipun bentuknya sederhana, seperti yang telah dilakukan di semester 1 untuk metode papan bintang yang dimodifikasi menjadi BION meskipun mungkin tidak berlaku untuk seluruh anak kelas V. Pada bagian terakhir untuk pelaksanaan belajar di rumah atau sekolah, orang tua memang memilih untuk belajar disekolah khususnya jika Covid 19 sudah usai, selain mempermudah dalam proses transfer ilmu, juga kegiatan karakter juga bisa lebih maksimal, karena apabila dirumah terkadang anak justru sulit dan tidak mau di ajar oleh orang tua mereka sendiri.

\section{KESIMPULAN}

Motivasi belajar memiliki hubungan yang sangat erat dengan prestasi siswa, jika hal tersebut tidak bisa di tingkatkan, maka hasil belajar juga tidak dapat optimal. Terlebih pada masa pandemi yang membuat motivasi sebagian siswa menurun. Penggunaan metode reward dan punishmen menjadi sebuah alternatif membuka pintu semangat siswa dalam menuntut ilmu. Berdasarkan hasil dan pembahasan yang telah di jabarkan, dapat disimpulkan bahwa penggunaan media BION dapat meningkatkan motivasi belajar siswa di rumah pada masa pandemi.

Beberapa hal yang dapat kita jadikan acuan adalah kenaikan indikator pada hasil observasi siswa, yaitu pengerjaan tugas, prosentase ketepatan waktu serta pemenuhan KKM.

Acuan lain yang dapat digunakan yaitu prosentase pada angket penelitian yang telah di berikan kepada siswa, terutama pada butir ke 3 tentang efektifitas pengaruh BION dalam meningkatkan motivasi. Hasil wawancara dengan orang tua secara garis besar memang ada perubahan dengan media BION. Hal lain yang di dapat dari wawancara adalah sulitnya meningkatkan motivasi siswa untuk belajar di rumah, karena anak terkadang kurang 
mengindahkan apa yang diminta orang tua, berbeda hal dengan apa yang diminta oleh guru, sehingga guru harus sekreatif mungkin memilah materi dan media agar mudah dipahami anak di rumah.

Proses kedepan dari keberhasilan BION ini akan penulis coba terapkan pada siswa kelas V di ajaran baru 2020/2021, karena dengan wacana pendidikan BDR secara permanen tentu harus menggunakan sebuah metode khusus untuk meningatkan semangat siswa. BDR sebenarnya bukan momok menakutkan bagi guru, jika mereka bersedia membuka pintu inovasi dan kreativitas untuk meningkatkan motivasi, yang berpengaruh terhadap prestasi siswa dalam mencerdaskan bangsa.

\section{UCAPAN TERIMA KASIH}

Dalam menyelesaikan best practice ini, penulis mengucapkan terima kasih kepada banyak pihak yang telah memberikan kesempatan untuk terus berinovasi ditengah masa pandemi lewat karya, disamping rekan sejawat dan tutor yang memberikan dorongan melaksanakan program. Ucapan terima kasih tersebut diberikan kepada :

1. Panitia Lomba Artikel Pembelajaran (Best Practice), UNP Kediri

2. Rektor Universitas Nusantara PGRI Kediri

3. Dekan FKIP Universitas Nusantara PGRI Kediri

4. Ketua Prodi. PGSD Universitas Nusantara PGRI Kediri

5. Bapak Korwil Pendidikan Kecamatan Watulimo dan Pengawas SDN 1 Ngembel yang terus mendorong untuk berinovasi

6. Kepala Sekolah SDN 1 Ngembel selaku tutor penulisan Best Practice dan rekan guru SDN 1 Ngembel, Kec. watulimo Kab. Trenggalek

7. Keluarga, Istri dan anakku tersayang.

\section{DAFTAR RUJUKAN}

Bilfaqih, Yusuf dan Qomarudin, M Nur. 2015. Esensi Pengembangan Pembelajaran Daring. Yogyakarta: Deepublish

Global monitoring of School closures causes by Covid-19. 
Retrieved from : https://en.unesco.org/covid19/educationresponse (diakses 2 Juni 2020)

Lestari F N dan Ulum W M. 2020. Analisis Bentuk Kedisiplinan Siswa Dalam Mengikuti Kegiatan Belajar Dengan Motivasi Belajar Siswa Kelas IV SDN I Gondosuli Gondang. Jurnal Pendidikan Dasar Nusantara. Vol. 5 No. 2. Hlm 318-329.

DOI: https://doi.org/DOI 10.29407/jpdn.v5i2.13554 (di akses tanggal 3 Juni 2020)

Maulidia, Isna. 2019. Penerapan Reward dan Punishment dalam Pembelajaran Qur'anHadits di Sekolah Dasar Kecamatan Muara Tiga Kabupaten Pidie. Tadabbur: Jurnal Peradaban Islam. Vol. 1 No. 1. Hlm 49-62.

Retrieved from : https://jim.ar-raniry.ac.id/index.php/tadabbur/article/view/51/36

(di akses tanggal 3 Juni 2020)

Oktiani, Ifni. 2017. Kreatifitas Guru dalam Memotivasi Peserta Didik. Jurnal Kependidikan Iain Purwokerto, Vol. 5 No. 2. Hlm 216-232.

DOI: https://doi.org/10.24090/jk.v5i2.1939 (di akses tanggal 4 Juni 2020)

Purwanto A, dkk. 2020. Studi Eksploratif Dampak Pandemi COVID-19 Terhadap Proses Pembelajaran Online di Sekolah Dasar. Edupsycounsjournal. Vol. 2 No. 1. Hlm 112.

Retrived From : https://ummaspul.e-journal.id/Edupsycouns/article/view/397/223

(di akses tanggal 3 Juni 2020)

Putra R.P, dkk. 2018. Pemberian Reward Dan Punishment Untuk Meningkatkan Motivasi dan Prestasi Belajar Mata Pelajaran Kearsipan Kelas X Administrasi Perkantoran SMK Wikarya Karanganyar. Prosiding Seminar Nasional Pendidikan Administrasi Perkantoran (SNPAP) 2018. Surakarta: 27 Oktober 2018. Hlm. 217-222.

Retrived from : https://jurnal.uns.ac.id/snpap/article/view/27942/21806 (di akses tanggal 2 Juni 2020)

Sugiyono, 2013. Metode Penelitian Pendidikan Pendekatan Kuantitatif, Kualitatif, dan R\&D. Bandung: Alfabeta 